\title{
PENGGUNAAN EKSTRAK KAYU NANGKA (Artocarpus heterophyllus) SEBAGAI BAHAN PEWARNA UNTUK KULIT
}

\author{
Emiliana K *, Widhiati *, Kuwatno*
}

\begin{abstract}
INTISARI
Penelitian ini bertujuan untuk mengetahui pengaruh penggunaan variasi kadar alum dan perlakuan mordanting terhadap ketahanan gosok cat .Zat warna alam dari ekstrak kayu nangka (Artocarpus heterophyllus) mempunyai ketahanan terhadap asam asetat cukup baik dengan nilai 3 pada skala grey scale tetapi ketahanan terhadap asam sulfat dan asam formiat kurang baik (nilai 1 dan nilai 2). Ketahanan terhadap basa (Natrium carbonat) menunjukkan hasil yang baik dengan nilai 4 pada skala grey scale. Zat warna alam tersebut dapat menyerap baik pada jaringan kulit kambing dan menghasilkan warna kuning yang rata serta mempunyai ketahanan warna yang baik terhadap ketahanan gosok cat baik secara kering maupun secara basah. Perlakuan variasi kadar alum $(1 \%, 2 \%, 3 \%)$ dan perlakuan mordanting (sebelum dan selama pewarnaan) tidak mempengaruhi ketahanan warna terhadap gosokan kering dan basah.
\end{abstract}

\begin{abstract}
The objective of this experiment was to evaluate the effect Alum content and time of mordanting on the rub fastness. Natural dyes from wood dyes Artocarpus heterophyllus haved an intermediate acid resistance (acetic acid), a good alkali resistance (natrium carbonat) but they had very low sulphur acid resistance and low formic acid resistance. Natural dyes from wood dyes Artocarpus heterophyllus could be used as colouring matter on goat skin dyeing proses with a good absorption on the goat skin fibres. The colour being uniformly distributed throughout the substance of the fibre goat skin. Their rub fastness was a good (dry and wet). The variation of amounts alum (1\%,2\%,3\%) and treatment of mordanting (before and during dyeing) did not influence on rub fastness (dry and wet).
\end{abstract}

\section{PENDAHULUAN}

Kulit yang diwarnai akan menambah daya tarik dan dapat menyesuaikan untuk model fashion. Pewarnaan yang tepat pada kulit tidak hanya mempertinggi nilai produk tersebut tetapi juga dapat menyumbangkan kualitas kulit secara umum (Sarkar, 1995).

Banyak tumbuhan lokal yang menghasilkan zat warna alam tetapi belum dimanfaatkan sebagai bahan pewarna untuk kulit. Inventarisasi zat warna alam dari tumbuhan lokal yang dilakukan oleh Emiliana dkk, 1999 menunjukkan bahwa ekstrak kayu nangka dapat berikatan dengan serat-serat kulit kaki ayam dan dapat memberikan warna kuning pada kulit.

Pohon nangka merupakan famili Moraceae, genus Artocarpus, species Heterophyllus, kelas Decosyledoneae, devisio Spermatophyta. Nama Indonesià nangka, nama daerah jawa : nongko. Kayu nangka mengandung zat warna kuning yang disebut dengan morin (Lemmens 
dan Soetjipto, 1992).

Morin adalah merupakan derivat dari flavon yang terdapat pada beberapa famili Moraceae Struktur molekul morin adalah seperti pada Gambar 1 berikut ini :

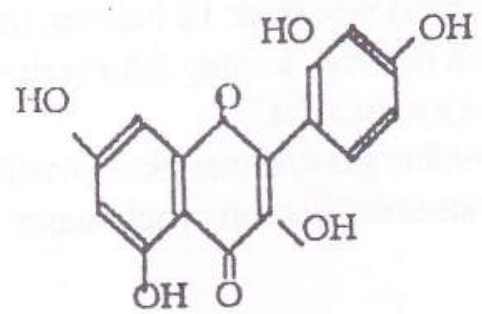

Gambar 1

Struktur molekul zat warna morin

(Lemmens dan Soetjipto, 1992)

Sifat-sifat fisika zat warna morin menurut Soewadji dkk, 1980 adalah sebagai berikut:

Warna larutan kuning, larut dalam air, asam, pyridin dan trichlor acetat, alkohol dan aceton, maka dapat dikategorikan sebagai zat warna yang larut dalam air (water soluble dyes)

Sifat-sifat kimia :

Warna mula-mula adalah kuning, dengan adanya basa akan berwarna coklat, sedangkan dalam suasana asam menjadi kuning pucat.

Pada pH 6,7 warna kuning ; $\mathrm{pH} 8,7$ warna kuning coklat, $\mathrm{pH} \mathrm{10,4}$ warna coklat dan $\mathrm{pH}$ 4,5 warna kuning pucat.

Dengan larutan $\mathrm{K} 2 \mathrm{Cr} 2 \mathrm{O} 7$ berwarna kuning dan dengan $\mathrm{Al}$ (tawas) warna tetap.

Ekstrak larutan dari kayu nangka merupakan zat warna kayu (wood dyes). Semua zat warna kayu adalah mordanting dyestuffs (Koteswara,1985). Perlakuan mordanting adalah perlakuan yang dapat memberikan sarana dalam penyerapan zat warna alam, membentuk jembatan kimia antara molekul zat warna dan jaringan /serat dan dapat mempercepat pembentukan warna serta dapat mempengaruhi warna akhir dari zat warna alam (Lemmens dan Soetjipto, 1992). Mordan yang digunakan umumnya dalam bentuk garam-garam metal seperti aluminium, besi, "tin", krom,"copper" (Koteswara, 1985; Lemmens dan Soetjipto, 1992; Sarkar ,1995). Perlakuan mordanting dapat dilakukan sebelum, selama dan sesudah proses pewarnaan (Belfer.N, 1972).

Reaksi zat warna alam pada kulit sama dengan bahan penyamak nabati, kecuali warna kayu yang secara khusus diseleksi karena nilai warnanya kuat dan dalam aplikasinya ke kulit dengan cara yang sama seperti pada cat asam (Sharphouse,1983).

Penggunaan zat warna alam dari kayu ada keuntungan dan kerugiannya.Keuntungannya adalah mempunyai kemampuan membentuk range warna komplek dengan garam-garam metal dan mempunyai efek penyamakan pada kulit serta meningkatkan daya isi (Sharphouse, 1983 ; Sarkar, 1995) . Disamping itu warna dari ekstrak kayu mempunyai sifat pewarnaan pada "grain" dan "flesh" dengan "shade" yang sama (Sarkar,1995). Kerugiannya adalah bila digunakan dalam jumlah yang berlebihan maka membuat kulit menjadi keras. Jumlah warna yang digunakan tergantung pada sifat bahan baku. Untuk kulit kerbau dan sapi diperlukan persentase yang tinggi (Sarkar,1995). 


\section{BAHAN DAN METODE}

\section{Bahan penelitian}

Kulit kras dari kulit kambing yang telah disamak masak dengan kombinasi bahan penyamak (krom, syntan dan nabati) sebanyak 12 belahan untuk dibuat menjadi kulit glace. Obat-obat yang digunakan: Alum (tawas), kuning telur (sebagai minyak) dan minyak nabati, asam asetat dan ekstrak larutan kayu nangka.

Alat penelitian terdiri dari ember plastik, mangkok plastik, sendok plastik, panci,kompor, saringan,timbangan, drum penyamakan, alat uji crock meter .

\section{Cara penelitian}

Prosedur pewarnaan kulit menggunakan zat warna alam meliputi 3(tiga ) tahap :

1. Tahap pembuatan ekstrak larutan zat warna alam

- Kayu nangka berupa kayu pasahan dikecilkan ukurannya dengan ukuran 2 × $2 \mathrm{~cm}$

- Membuat ekstrak larutan dengan menggunakan pelarut air dengan perbandingan berat bahan : berat air ( $1: 10)$, lalu direbus sampai volume larutan tinggal setengahnya . Ulangi perebusan tersebut dengan menambahkan air lagi dengan perbandingan yang sama sampai 2 (dua) kali, sehingga didapat 3 (tiga) larutan. Larutan hasil perebusan ke 1 sebagai larutan 1 , hasil perebusan ke 2 sebagai larutan 2 dan hasil perebusan ke 3 sebagai larutan 3 (paling encer).

2. Tahap proses pewarnaan dengan zat warna alam

Pewarnaan dilakukan dengan menggunakan 2 (dua) macam mordan yaitu krom alum . Krom selain berfungsi sebagai mordan juga berfungsi sebagai bahan penyamak demikian juga alum. Perlakuan pemberian mordan alum divariasi yaitu perlakuan sebelum pewarnaan dan perlakuan pada saat pewarnaan / selama pewarnaan (alum dicampur dengan ekstrak larutan zat warna). Jumlah alum yang digunakan bervariasi yaitu dengan kadar $1 \%, 2 \%$ dan $3 \%$. Masing-masing variasi digunakan 2 belahan kulit.

Diagram alir proses pewarnaan kulit kambing menggunakan ekstrak kayu nangka adalah sebagai berikut :

$200 \%$ air

$3 \%$ tawas, 2 jam

$200 \%$ larutan C, 30 ",drain $200 \%$ larutan B, 30 ', drain $200 \%$ larutan A, 30 “

tambah 1 jam, drain
Kulit kras (basah)

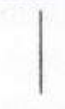

Mordanting

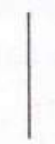

Pewarnaan
3. Tahap peng Pengujian d Uji yang dil

a. Uji keta formiat,

Pewarna

b. Uji ketah meter, st crock m

4. Analisis dat Menggunal

Hasil peneliti Hasil pe Tabel 1. K

$$
\mathrm{Pa}
$$

Ketahana

1.

2. $A$

3.

Ketahan

Nat:

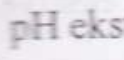


$150 \%$ air $40^{\circ} \mathrm{C}$

$+6 \%$ minyak, 1 jam

$+0,5 \%$ asam asetat, $20^{\prime}$

$+0,02 \%$ anti jamur, 15
Peminyakan<smiles>CCC1CCCC1</smiles>

Aging

Pelemasan

Pementangan

Gambar 2

Diagram Alir Proses Pewarnaan Kulit Dengan Zat Warna Alam

3. Tahap pengujian

Pengujian dilakukan di laboratorium PMNK BBKKP.

Uji yang dilakukan meliputi :

a. Uji ketahanan warna dari ekstrak larutan kayu nangka terhadap asam (sulfat, formiat, asetat) dan basa (Natrium carbonat), sesuai SNI.06 -2867 - 1992, Serbuk Pewarna Asam Untuk Kulit (DSN,1982).

b. Uji ketahanan warna terhadap gosok kering dan basah dengan menggunakan alat crock meter, sesuai SNI . 06 - 0996 - 1989, Kekuatan gosok cat tutup kulit jadi dengan alat crock meter, cara uji (DSN, 1989).

4. Analisis data

Menggunakan analisis variansi satu jalur (one way anova).

\section{HASIL DAN PEMBAHASAN}

\section{Hasil penelitian}

Hasil penelitian disajikan berturut-turut pada Tabel 1, Tabel 2 dan Tabel 3.

Tabel 1. Ketahanan zat warna (asam dan basa) dan $\mathrm{pH}$ ekstrak larutan kayu nangka

\begin{tabular}{|c|c|c|}
\hline Parameter Uji & Hasil Uji & $\begin{array}{c}\text { Persyaratan } \\
\text { SNI.06 - 2867 -1992 }\end{array}$ \\
\hline Ketahanan terhadap asam: & nilai 1 & minimum 3 \\
1. Asam sulfat & nilai 2 & minimum 3 \\
2. Asam format & nilai 3 & minimum 3 \\
3. Asam asetat & nilai 4 & minimum 3 \\
Ketahanan terhadap basa : & nilai 5 & $4,0-7,0$ \\
Natrium carbonat & & \\
pH ekstrak larutan kayu & & \\
\hline
\end{tabular}


Tabel 2. Ketahanan gosok cat secara kering

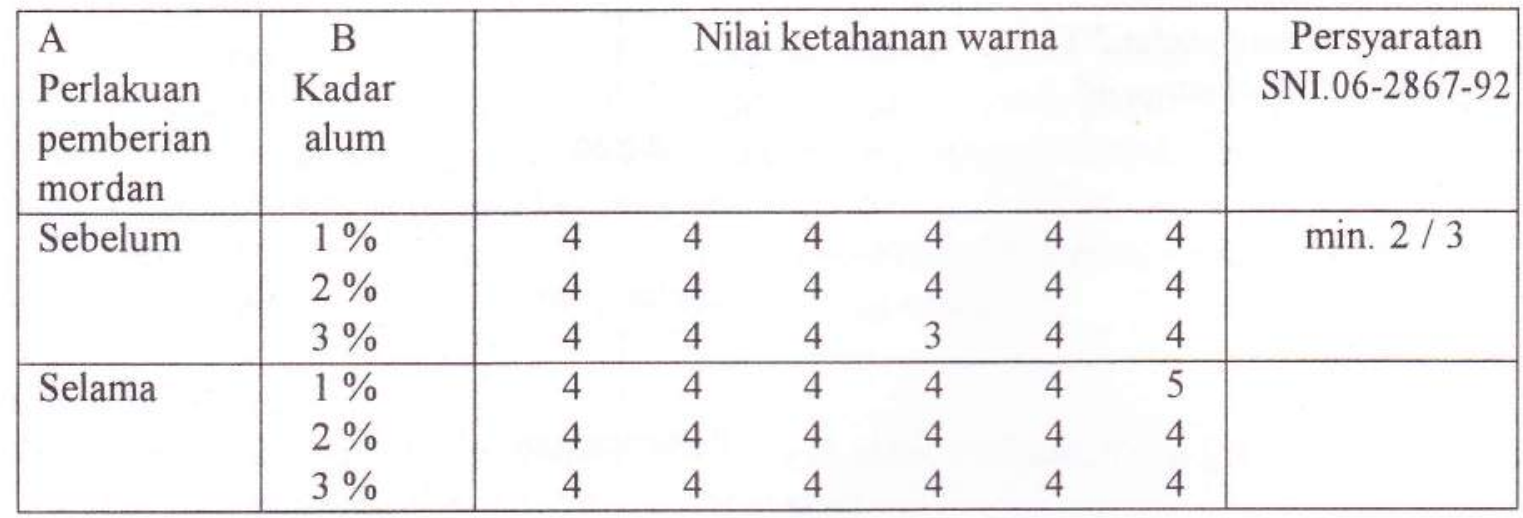

Tabel 3. Ketahanan gosok secara basah

\begin{tabular}{|l|c|cccccc|c|}
\hline $\begin{array}{l}\text { A } \\
\text { Perlakuan } \\
\text { pemberian } \\
\text { mordan }\end{array}$ & $\begin{array}{c}\text { B } \\
\text { Kadar } \\
\text { alum }\end{array}$ & & & & & & & \\
\hline Sebelum & $1 \%$ & 4 & 4 & 4 & 3 & 3 & 3 & min. 2 \\
& $2 \%$ & 4 & 4 & 4 & 3 & 4 & 3 & \\
& $3 \%$ & 4 & 4 & 4 & 4 & 3 & 3 & \\
\hline Selama & $1 \%$ & 4 & 4 & 4 & 4 & 4 & 3 & \\
& $2 \%$ & 4 & 4 & 4 & 4 & 4 & 4 & \\
& $3 \%$ & 4 & 4 & 4 & 3 & 3 & 3 & \\
\hline
\end{tabular}

\section{Pembahasan}

1. Ketahanan warna terhadap asam dan basa

Hasil uji ketahanan warna terhadap asam ternyata bahwa warna dari ekstrak kayu nangka mempunyai ketahanan yang cukup baik terhadap asam asetat (nilai 3) dan memenuhi persyaratan SNI. 06 -2867-1992, Serbuk Pewarna Asam Untuk Kulit yang mempersyaratkan minimal nilai 3 . Tetapi terhadap asam sulfat dan asam formiat nilainya kurang baik (nilai 1 untuk asam sulfat dan nilai 2 untuk asam formiat), sehingga disarankan pada fiksasinya menggunakan asam asetat agar warna asli dari zat warna tersebut tidak berubah. Menurut Sarkar (1995) dan Koteswara (1983) untuk fiksasi dapat menggunakan asam formiat atau asam asetat atau asam sulfat. Namun untuk asam sulfat jarang digunakan karena merupakan asam keras (Koteswara,1983). Ketahanan warna terhadap basa menghasilkan nilai cukup baik (nilai 4) dan memenuhi persyaratan SNI.06-2867-1992 yang mempersyaratkan minimal nilai 3 .

2. $\mathrm{pH}$

Hasil pengukuran $\mathrm{pH}$ larutan ekstrak kayu nangka, menunjukkan nilai 5 berarti memenuhi persyaratan $\mathrm{pH}$ untuk pewarna kulit $(4,0-7,0)$ dan warna dari ekstrak kayu nangka merupakan zat warna asam. 
3. Ketahanan gosok cat secara kering

Hasil analisis variansi menunjukkan bahwa perlakuan pemberian mordan (A), dan kadar alum (B) berpengaruh nyata terhadap ketahanan gosok cat secara kering

$(\mathrm{P}<0,05)$. Interaksi kedua perlakuan tersebut tidak nyata mempengaruhi ketahanan gosok cat secara kering $(\mathrm{P}>0,05)$. Nilai rata-rata ketahanan gosok adalah 4 (tidak luntur) dan nilai tersebut lebih tinggi dari yang dipersyaratkan yaitu minimal $2 / 3$ (SNI.06.2867 -1992, Serbuk Pewarna Asam Untuk Kulit).

4. Terhadap ketahanan gosok secara basah

Hasil analisis variansi menunjukkan bahwa perlakuan pemberian mordan (A), kadar alum (B) dan interaksi kedua perlakuan tersebut tidak nyata mempengaruhi ketahanan gosok cat secara basah. ( $\mathrm{P}>0,05)$, nilai rata -rata ketahanan gosok adalah 4 (tidak luntur) dan nilai tersebut lebih tinggi dari yang dipersyaratkan yaitu minimal 2 (SNI.06.2867 -1992, Serbuk Pewarna Asam Untuk Kulit).

Hasil pembahasan diatas menunjukkan bahwa penggunaan alum $1 \%$ sudah cukup efisien dan perlakuan pemberian mordan lebih efektif dilakukan selama proses pewarnaan dengan cara mencampur alum kedalam ekstrak larutan. Tidak adanya pengaruh jumlah kadar alum yang digunakan disebabkan karena mordan yang digunakan 2 (dua ) macam yaitu krom dan alum. Kadar krom sebanyak $10 \%$ (yang diberikan waktu penyamakan) dan kadar alum jumlahnya bervariasi $(1 \%, 2 \%, 3 \%)$ sehingga penggunaan 2 macam mordan tersebut dapat mengikat zat warna lebih kuat. Besarnya jumlah mordan yang diberikan ini mungkin sangat mempengaruhi didalam penyerapan antara molekul zat warna dan jaringan kulit sehingga zat warna kayu nangka dapat terikat dengan kuat, karena mordan berfungsi sebagai sarana dalam penyerapan zat warna alam (Koteswara, 1985; Lemmens dan Soetjipto,1992, Sarkar,1995). Fungsi alum selain sebagai mordan juga dapat memperbaiki range warna pada penggunaan warna alam dari eksktrak kayu (natural dyewood extract) (Sykes RL, 1994) dan dapat menstabilkan warna asli dari ekstrak kayu nangka (Soewadji dkk, 1980). Penggunaan kadar alum(1\%,2\%, 3\%) relatif lebih sedikit dibanding dengan kadar krom (10\%) sehingga pengaruhnya terhadap ketahanan gosok cat tidak begitu nyata. Perlakuan pemberian mordan (sebelum dan selama) juga tidak berpengaruh pada ketahanan gosok cat . Menurut Belfer N, 1972, penggunaan mordan dapat dilakukan sebelum, selama dan sesudah pewarnaan.

Hasil uji $\mathrm{pH}$, ketahanan warna terhadap asam dan basa serta ketahanan gosok cat secara kering dan basah, dapat dikemukakan bahwa ekstrak larutan nangka dapat digunakan sebagai bahan pewarna kulit dan pada perlakuan fiksasi sebaiknya menggunakan asam asetat. Formulasi yang optimal diperoleh pada kombinasi perlakuan kadar alum $1 \%$ dengan perlakuan pemberian mordan selama proses pewarnaan dan proses penyamakan kulit menggunakan bahan penyamak krom $10 \%$, ekstrak larutan kayu nangka yang digunakan dengan perbandingan $1: 10$.

\section{KESIMPULAN}

Dari hasil pembahasan dapat disimpulkan sebagai berikut :

1. Warna alam dari ekstrak kayu nangka merupakan zat warna asam, dapat digunakan sebagai bahan pewarna untuk kulit, mempunyai ketahanan terhadap asam asetat cukup baik 
(nilai 3 ) dan ketahanan terhadap basa (Natrium carbonat) baik (nilai 4) serta memenuhi persyaratan SNI.06 -2867-1992, Serbuk Pewarna Asam Untuk Kulit .

2. Mempunyai ketahanan warna yang baik terhadap ketahanan gosok cat baik secara kering maupun secara basah dengan nilai rata-rata 4 (diatas persyaratan SNI. 06 -2867 - 1992), tetapi ketahanan terhadap asam sulfat dan asam formiat kurang baik ( nilai 1 dan 2).

3. Kadar alum $(1 \%, 2 \%$ dan $3 \%)$ tidak mempengaruhi ketahanan gosok cat baik secara kering maupun secara basah .Demikian juga perlakuan pemberian mordan (sebelum dan selama) tidak mempengaruhi ketahanan gosok cat baik secara kering maupun secara basah.

4. Formula optimal pada proses pewarnaan kulit kambing menggunakan warna dari ekstrak kayu nangka ( $1: 10$ ) adalah dengan menggunakan kadar alum 1\% (sebagai mordan), perlakuan pemberian mordan dilakukan selama proses pewarnaan dan menggunakan krom sebanyak $10 \%$ sebagai bahan penyamak dan sebagai mordan.

\section{DAFTAR PUSTAKA}

Dewan Standardisasi Nasional (DSN), 1992, Standar Nasional Indonesia SNI 06 - 2867 1992 : Serbuk Pewarna Untuk Kulit, Departemen Perindustrian

Belfer N, 1972, Designing in Batik and Tie Dye, David Publications Inc. Warcester Massachusset

K.Emiliana ,Widhiati,Emi Sulistyo Astuti, Kuwatno, 1999, Inventarisasi Zat Warna Alam Dari Tumbuhan Lokal Untuk Industri Kulit, Laporan Teknis Intern, BBKKP.

Koteswara, 1985, Dyeing and Finishing of Leather, Central Leather Research Institute, Adyar Madras 600 - 020

Lemmens R.H.M.J dan Soetjipto NW, 1992, Dye and TanninProducing Plants, Prosea Foundation, Bogor

Sarkar, 1995, Theory Practice Leather Manufacture, The Author Second Avenue Mahadma Gandi Road Madras

Sharphouse JR, 1983, Leather Technician's Hand Book, Leather Producer's Association Thomas Street London SE 1

Soewadji, Sutikno,Handayani D, 1980, Laporan Penelitian Tentang Pemanfaatan Sumber

Warna Nabati Sebagai Pewarna Dalam Industri Makanan dan Minuman ,BPK Semarang 